УдК 347.952(477) \}

DOI https://doi.org/10.32837/npnuola.v28i0.703

\author{
T. А. Стоянова, Л. А. Островська
}

\title{
ПЕРЕШКОДИ У ЗАСТОСУВАННІ ОБМЕЖУВАЛЬНОГО ПРИПИСУ ЯК ЗАСОБУ ПРОТИДІЇ ДОМАШНЬОМУ НАСИЛЬСТВУ: НАЦІОНАЛЬНА СУДОВА ПРАКТИКА ТА ПРАКТИКА ЄВРОПЕЙСЬКОГО СУДУ $З$ ПРАВ ЛЮДИНИ
}

Як свідчить статистика, за період карантинних обмежень, викликаних COVID-19 (у статті взятий порівняльний аналіз статистичних даних за період карантинних обмежень), випадки домашнього насильства зросли приблизно на 30\% у країнах всього світу [1, с. 113]. Можна зробити висновок, що проблема домашнього насильства, що існувала в латентному вигляді, у зв'язку із провокацією самоізоляції та перебуванням «постраждалої особи» - жертви та кривдника в одному приміщенні, спровокувала кризу та змусила звернутися за допомогою у разі здійснення домашнього насилля, висвітила масштабність замовчуваної проблеми. Не можна стверджувати, що проблеми домашнього насилля або насилля проти жінок не було і з'явилася тільки на карантині, ні таке твердження є неправильним, проблема набрала ваги, оскільки стресові, незвичні фактори у вигляді страху за майбутнє, обмеженого простору та перебування «постраждалої особи» в одному приміщенні із «кривдником», неможливість зміни уваги та відволікання на повсякденні справи (школи, робота, друзі, подорожі тощо), змусили подивитися реаліям замовчуваної насильницької поведінки в очі та звернутися по допомогу в наявні інстанції. Дослідити всі фактори-перешкоди в протидії домашньому насиллю або ж насиллю проти жінок - це окрема комплексна, багатостороння тема, предметом же дослідження у цій роботі стануть саме окремі аспекти - перешкоди у застосуванні обмежувального припису у разі застосування психологічного насилля.

Стосовно практичного застосування такого механізму протидії домашньому насиллю та насиллю проти жінок, як обмежувальний припис, можна виокремити багато чинників, що перешкоджають його застосуванню. I не всі такі чинники мають коріння суто в полі законодавчого регулювання (наявних колізій у праві, не діючих норм) або ж у відсутності дієвого правоохоронюваного механізму. Розглядати питання механізму протидії такого виду насилля слід насамперед за допомогою комплексного підходу, з урахуванням аналізу судової (національної, європейської) практик, законодавчого регулювання та основних психологічних характеристик понять 
«кривдник» та «постраждала особа». Саме такий підхід, як видається, зможе перейти до позиції «право для людини», а не «людина для права».

Як свідчить судова практика, зокрема Постанова Верховного Суду України від 28 квітня 2020 року у справі № 754/11171/19 (далі - Постанова), суди, приймаючи рішення про видачу обмежувального припису, керуються вже вкрай очевидними ознаками вчинення насилля і насамперед орієнтуються на існування попереднього звернення до органів Національної поліції щодо вчинення насильницьких дій фізичного, сексуального, а потім вже психологічного насилля. Зокрема, в Постанові зазначається: «Суди, приймаючи рішення про видачу обмежувального припису, для забезпечення дієвого та ефективного захисту керувалися тим, що існує високий рівень вірогідності продовження чи повторного вчинення домашнього насильства, настання тяжких або особливо тяжких наслідків його вчинення щодо постраждалої особи, такі ризики є реальними». До звернення до суду з вимогою про видачу обмежувального припису постраждала особа, як зазначено у справі, неодноразово зверталася до працівників поліції із заявою про відкриття кримінального провадження, у Службу у справах дітей та сім’ї Деснянської районної в місті Києві державної адміністрації, Центр соціальних служб сім’і, дітей та молоді Деснянської районної в місті Києві державної адміністрації [2]. Тобто перш ніж звернутися до суду задля видачі обмежувального припису, постраждала особа неодноразово зверталася до позасудових механізмів захисту від домашнього насильства. I з огляду на інші приклади судових рішень, усталеною практикою в таких справах стає те, що видача судом обмежувального припису відбувається тоді, коли у справі є докази про попереднє звернення до позасудових механізмів захисту проти домашнього насильства, і тільки у разі продовження дій або бездіяльності з боку кривдника суди ухвалюють рішення про задоволення вимог про видачу обмежувального припису. Тобто можливість захистити свої права у разі вчинення психологічного насильства без фізичного, з приводу якого не було попереднього звернення до правоохоронних чи державних органів захисту прав дітей, стає практично неможливим.

Якщо звернутися до практики Європейського суду 3 прав людини (далі - ЄСПЛ), то перш за все слід навести приклад останнього його рішення «Левчук проти України» (заява № 17496/19), що було ухвалене у вересні 2020 й стало першим рішенням проти України щодо домашнього насильства [3]. У цій справі ЄСПЛ дійшов висновку, що Україною порушено позитивні зобов'язання захисту прав людини на повагу до приватного життя, зокрема ст. 8 Конвенції про захист прав людини та основоположних свобод, що гарантує право на повагу до приватного та сімейного життя [4]. Слід зазначити, що напряму зазначена Конвенція не присвячена регулюванню домашнього насилля та насилля проти жінок, оскільки існує спеціальна Стамбульська Конвенція 2011 року [5], й ЄСПЛ у своєму рішенні це зазначив, посилаючись на рішення «Volodina v. Russia», заява № 41261/17 від 9 липня 2019 р., де суд спирався на універсально застосовні стандарти у сфері протидії насильству щодо жінок, зокрема, Конвенцію про ліквідацію дискримінації щодо жінок (CEDAW) 1979 р., звіти Спеціальних доповідачів ООН, Рекомендацію Комітету міністрів Ради 
Європи від 30 квітня 2002 року «Про захист жінок від насильства» та безпосередньо на Стамбульську Конвенцію.

3 одного боку, таке рішення є показовим для України, як визнання на рівні ЄСПЛ невиконання національними судами зобов'язань щодо забезпечення прав людини, зокрема права на повагу приватного та сімейного життя та прав жінок на захист від домашнього насилля, а також захист від домашнього насилля, також ним акцентується увага на існуванні блоку законодавчих актів щодо протидії домашньому насиллю та насиллю проти жінок. 3 іншого ж боку, проаналізувавши історію справи, можна дійти того ж самого висновку, що й після аналізу національної судової практики, зокрема, що постраждала-заявниця перш ніж звернутися до суду, неодноразово зверталася до численних правоохоронних органів з приводу насильницьких дій, але навіть за наявності численних доказів застосування позасудових спроб заявниці захистити себе та своїх дітей від кривдника в національних судах не вдалося.

Тобто, як видається, отримати своєчасно захист у разі здійснення домашнього насилля складно. I це є одним аспектом-перешкодою в тому, що механізм протидії домашньому насиллю дієво запрацює. 3 іншого боку, існує інша перешкода, яку не можна минути у разі розгляду зазначених справ, і вона стосується питань зловживання обмежувальним приписом для вирішення зовсім інших спорів постраждалою особою. Наприклад, застосування обмежувального припису з обов'язком усунення перешкод у користуванні майном, що є об’єктом права спільної сумісної власності або особистою приватною власністю постраждалої особи, чи заборона перебувати в місці спільного проживання (перебування) з постраждалою особою, що визначені п. 1 ч. 2 ст. 26 Закону України «Про запобігання та протидію домашньому насильству» [6], задля продажу спільного майна або задля вчинення зворотної маніпуляції стосовно кривдника шляхом обмежувального припису, тобто не задля свого захисту чи захисту прав дітей, а задля нападу чи примушування до вчинення кривдником якихось інших дій, напряму не пов'язаних із припиненням вчинення насилля над постраждалою, а на іï користь.

Підбиваючи підсумок, слід зазначити, що застосування обмежувального припису ускладнюється двома чинниками: 1) видачею обмежувального припису судом тільки після неодноразового попереднього звертання до правоохоронних органів, 2) використання постраждалою особою такого інституту, як інструмент помсти, чи з метою вирішити майновий спір між нею та кривдником. Такий висновок, безумовно, не претендує на остаточну істинність, не вичерпує всіх підстав домашнього насильства, що може статися не тільки між колишнім подружжям, але й іншими членами сім’і. Але слід підкреслити, що саме неможливість сумісного проживання, набрання дистанції між колишнім подружжям $\mathrm{i} \in$ найчастішою підставою звернення до суду.

Слід дійти ще одного висновку щодо правової невизначеності поняття «психологічне насильство». Можна допустити, що у разі розгляду зазначеної категорії справ перед судом постає складне питання щодо формування предмета доказування: які обставини в нього включити, щоб можна було 
зробити правильний висновок щодо наявності підстав видачі обмежувального припису. 3 фізичним насиллям усе ж таки легше здійснити доказування - воно очевидне, а щодо психологічного встановити його дуже складно, хоча наслідками психологічного насилля є й те, що воно передує фізичному, може стати попереднім кроком до застосування фізичного насильства. Під час вирішення справ про видачу обмежувального припису перед судом, коли підставою видачі обмежувального припису є вчинення психологічного насилля, постає завдання - встановити та довести факт вчинення психологічного насильства. Як свідчить нерадісна статистика, на яку посилався ЄСПЛ у рішенні «Левчук проти України», зокрема на дані дослідження ОБСЕ щодо насильства проти жінок, згідно з яким $26 \%$ жінок в Україні переживали фізичне та / або сексуальне насильство з боку нинішнього або колишнього партнера. Дві третини жінок (65\%) зазнавали психологічного насильства з боку інтимних партнерів. Це перевищує середній показник гендерно зумовленого насильства по ЄС на $43 \%$ і є вищим, ніж у будь-якій країні ЄС. Проте лише $7 \%$ жінок, які пережили насильство від нинішнього партнера, і $12 \%$ тих, хто пережив насильство від попереднього партнера, повідомляли про свій досвід у поліцію. Хоча наведені дані стосуються і фізичного, і сексуального насильства, цифри щодо психологічного насильства свідчать про більш сувору реальність, що, на жаль, як видається із попереднього висновку щодо аналізу національної судової практики застосування обмежувального припису у випадках психологічного насильства, є вкрай неможливим. Отже, слід проаналізувати положення чинного законодавства щодо таких понять, як «домашнє насильство» та його різновиду «психологічне насильство».

Як закріплює ст. 1 Закону України «Про запобігання та протидію домашньому насильству», під домашнім насильством розуміється діяння (дії або бездіяльність) фізичного, сексуального, психологічного або економічного насильства, що вчиняються у сім'і чи в межах місця проживання або між родичами, або між колишнім чи теперішнім подружжям, або між іншими особами, які спільно проживають (проживали) однією сім'єю, але не перебувають (не перебували) у родинних відносинах чи у шлюбі між собою, незалежно від того, чи проживає (проживала) особа, яка вчинила домашне насильство, у тому самому місці, що й постраждала особа, а також погрози вчинення таких діянь. Із законодавчого визначення слід виокремити такі ознаки саме домашнього насилля:

1) діяння (дія або бездіяльність) фізичного, сексуального, психологічного або економічного насильства. Тобто, по-перше, суду під час розгляду такої категорії справ слід встановити обставини щодо наявності дії або бездіяльності конкретної особи - кривдника, які мають ознаки сексуального, психологічного або економічного насильства;

2) погрози вчинення таких діянь. Тобто суд, вирішуючи питання про застосування обмежувального припису, не тільки бере до уваги вже здійснений факт діяння (дії або бездіяльності) домашнього насильства, а також погрози вчинення таких діянь;

3) вчиняються у сім’i чи в межах місця проживання або між родичами, або між колишнім чи теперішнім подружжям, або між іншими особами, які 
спільно проживають (проживали) однією сім'єю, але не перебувають (не перебували) у родинних відносинах чи у шлюбі між собою, незалежно від того, чи проживає (проживала) особа, яка вчинила домашнє насильство, у тому самому місці, що й постраждала особа.

Ключовою ознакою домашнього насильства $є$ те, що між «кривдником» та «постраждалою особою» є сімейні або колишні сімейні стосунки, чи між особами, які проживають разом однією сім'єю, але не перебувають (не перебували) у родинних відносинах чи у шлюбі між собою, незалежно від того, чи проживає особа, яка вчинила домашнє насильство у тому самому місці, що й постраждала особа. Слід звернутися до положень ст. 3 Сімейного кодексу, що визначає поняття сім’і, зокрема: сім’ю складають особи, які спільно проживають, пов'язані спільним побутом, мають взаємні права та обов'язки, в тому числі подружжя, яке вважається сім'єю і тоді, коли дружина та чоловік у зв'язку з навчанням, роботою, лікуванням, необхідністю догляду за батьками, дітьми та з інших поважних причин не проживають спільно. Сім'я створюється на підставі шлюбу, кровного споріднення, усиновлення, а також на інших підставах, не заборонених законом і таких, що не суперечать моральним засадам суспільства. Також, як зазначено, дитина належить до сім’ї своїх батьків і тоді, коли спільно з ними не проживає [7].

Як зазначає п. 14 ст. 1 Закону України «Про запобігання та протидію домашньому насильству» психологічне насильство - форма домашнього насильства, що включає словесні образи, погрози, у тому числі щодо третіх осіб, приниження, переслідування, залякування, інші діяння, спрямовані на обмеження волевиявлення особи, контроль у репродуктивній сфері, якщо такі дії або бездіяльність викликали у постраждалої особи побоювання за свою безпеку чи безпеку третіх осіб, спричинили емоційну невпевненість, нездатність захистити себе або завдали шкоди психічному здоров'ю особи.

Як видається, визначення психологічного насилля $€$ неоднозначним, законодавець не дає конкретних ознак психологічного насильства, а перелічує випадки, коли дія або бездіяльність може вважатися психологічним насильством, 3 акцентом на репродуктивну функцію жінки. Отже, підсумуємо та проаналізуємо, що $є$ психологічним насиллям як підставою застосування обмежувального примусу:

1) словесні образи, у тому числі щодо третіх осіб;

2) приниження;

3) переслідування, залякування.

Як видається 3 продовження такої норми, цей перелік не $€$ вичерпним, кожна із зазначених дій повинна мати певну мету - бути спрямованою на обмеження волевиявлення особи, якщо такі дії або бездіяльність викликали у постраждалої особи побоювання за свою безпеку чи безпеку третіх осіб, спричинили емоційну невпевненість, нездатність захистити себе або завдати шкоди психічному здоров'ю особи. Також законодавець встановлює, але це не зовсім ясно прописане в нормі, що під психологічне насилля підпадає контроль у репродуктивній сфері. Незрозуміло у зв'язку із тим, що саме контролюється: якщо один з подружжя хоче мати дітей, а інший не хоче, де та грань стосовного спричинення психологічного насилля щодо контролю репродуктивної функції? Якщо один з подружжя хоче 
мати дітей, а інший вживає протизаплідні засоби? А вживання протизаплідних засобів іншим з подружжя спричиняє психологічні страждання іншому з подружжя? Таких питань чимало, й можна зробити висновок, що саме невизначеність психологічного насилля, з одного боку, та широкий спектр для зловживання таким засобом захисту прав - з іншого, створюють неможливість ефективного застосування обмежувального припису.

Як один з варіантів вирішення зазначеної колізії пропонується запровадити обов'язкову участь профільного з питань психологічного насилля психолога у справах про видачу обмежувального припису для надання обов'язкового висновку з питань наявності вчинення психологічного насилля та наявності у постраждалої особи побоювання за свою безпеку чи безпеку третіх осіб, що спричинили емоційну невпевненість, нездатність захистити себе або завдати шкоди психічному здоров'ю особи. Це може бути конкретним кроком у механізмі реалізації державної програми запобігання та протидії домашньому насильству, що затверджена Постановою Кабінету Міністрів України від 24 лютого 2021 № 145 «Питання Державної соціальної програми запобігання та протидії домашньому насильству та насильству за ознакою статі на період до 2025 року» [7].

\section{Література}

1. Tatiana Stoyanova, Grygorii Tripulskyi, Liudmila Ostrovska. Pandemic of home violence. Jus Humani Law Journal. Vol. 9. No. 2. 2020. Pp. 115-136 (Web of Science Core Collection). URL: http:/ / iushumani.org/index.php/iushumani/article/view/246.

2. Постанова Верховного Суду (Касаційний цивільний суд) від 28.04.2020 № у справі 754/11171/19. Офіиійний сайт Верховної Ради України. URL: : https://verdictum. ligazakon.net/document /89034240?utm_source=biz.ligazakon.net\&utm_medium=news\&utm_ content=bizpress05\&_ga=2.86953758.760018352.1624900910-1824888847.1537916886.

3. "Levchuk v. Ukraine" (Application No. 17496/19). URL: https:// hudoc.echr.coe.int/eng \# $\{\%$ 22itemid $\% 22:[\% 22001-203931 \% 22]\}$.

4. Конвенція про захист прав людини та основоположних свобод : Закон України № 475/97ВР від 17.07.1997. Офіційний сайт Верховної Ради України. URL: http://zakon3.rada.gov. ua/laws/show/995_004.

5. Стамбульская Конвенция: что написано в скандальном документе. ГРАНИ.LV, 11.05.2016. URL: https:/ / www.grani.lv/latvia/68218-stambulskaya-konvenciya-chto-napisano-vskandalnom-dokumente.html.

6. Про запобігання та протидію домашньому насильству : Закон України від 7 грудня 2017 року. Офіційний сайт Верховної Ради України. URL: https:/ / zakon.rada.gov.ua/laws/ show / 2229-19\#Text.

7. Сімейний кодекс : Закон України від 10 січня 2002 року. Закон України від 7 грудня 2017 року. Офіційний сайт Верховної Ради України. URL: https: / / zakon.rada.gov.ua/laws / show / 2947-14/print.

8. Питання Державної соціальної програми запобігання та протидії домашньому насильству та насильству за ознакою статі на період до 2025 року : Постанова Кабінету Міністрів України від 24 лютого 2021 № 145. Офіційний сайт Верховної Ради України. URL: https:/ / zakon.rada.gov.ua/laws/show/145-2021-\%D0\%BF\#n16.

\section{А н о т а ц і я}

Стоянова T. A., Островська Л. А. Перешкоди у застосуванні обмежувального припису як засобу протидії домашньому насильству: національна судова практика та практика Європейського суду з прав людини. - Стаття.

У статті проаналізований механізм застосування обмежувального припису в Україні. Досліджена статистика звернень у зв'язку із вчиненням домашнього насильства у країнах світу, в Україні за роки карантинних обмежень, викликаних COVID-19. Досліджена 
національна судова практика застосування обмежувального припису, виявлено, що суди ухвалюють позитивне рішення про видачу обмежувального припису тільки за наявності попередніх, неодноразових звернень потерпілої до позасудових органів з вимогою про захист від домашнього насильства. Досліджена практика Європейського суду з прав людини щодо захисту від домашнього насильства.

Виокремлені актуальні чинники-перешкоди в ефективному застосуванні механізму видачі обмежувального припису судом: з боку судів видача обмежувального припису тільки у разі неодноразових попередніх звернень постраждалою до позасудових органів, з боку постраждалої використання обмежувального припису як інструменту помсти або вирішення майнових спорів, а не задля захисту від кривдника. Встановлено, що підставою існування таких перешкод $€$ правова невизначеність психологічного насильства як підстави видачі обмежувального припису в законодавстві. Розглянуто правове регулювання визначень домашнього насильства, психологічного насильства, а також проаналізовані ознаки психологічного насильства як підстави для видачі обмежувального припису. Встановлено, що саме розмитість, неточність ознак визначення психологічного насильства є перешкодою у формуванні предмета доказування в справах про видачу обмежувального припису, коли здійснюється психологічне насильство. Проаналізовані дії, що з точки зору законодавчого визначення $є$ психологічним насильством. Запропоновано запровадити обов'язкову участь з питань психологічного насилля психолога у справах про видачу обмежувального припису для надання обов'язкового висновку з питань наявності вчинення психологічного насилля та наявності у постраждалої особи побоювання за свою безпеку чи безпеку третіх осіб.

Надані рекомендації щодо обов’язкової участі психолога у разі розгляду справ про видачу обмежувального припису з підстави застосування психологічного насильства.

Ключові слова: обмежувальний припис, COVID-19, домашнє насильство, психологічне насильство, Європейський суд з прав людини.

\section{$\mathrm{S} \mathbf{u} \mathrm{m} \mathrm{m}$ a $\mathrm{r} \mathbf{y}$}

Stoianova T. A., Ostrovska L. A. Obstacles to the application of the restrictive provision as a means of combating domestic violence: national case law and the case law of the European Court of Human Rights. - Article.

The article analyzes the mechanism of application of the restrictive requirement in Ukraine. The statistics of appeals in connection with the commission of domestic violence in the countries of the world, in Ukraine during the years of quarantine restrictions caused by COVID-19 are studied. The national judicial practice of applying the restrictive order was studied, it was found that the courts make a positive decision to issue a restrictive order only in the presence of previous, repeated appeals of the victim to extrajudicial bodies with a request for protection from domestic violence.

The case law of the European Court of Human Rights on protection against domestic violence is studied.

Relevant obstacles to the effective application of the mechanism of issuing a restraining order by the court are singled out: by courts issuing a restrictive injunction only in case of repeated preliminary appeals by the victim to extrajudicial bodies, by the victim using the restrictive injunction as a tool of revenge or resolving property disputes. from the offender.

It is established that the basis for the existence of such obstacles is the legal uncertainty of psychological violence as a basis for issuing a restrictive prescription in the legislation. The legal regulation of the definitions of domestic violence, psychological violence is considered, as well as the signs of psychological violence are analyzed as grounds for issuing a restrictive order. It is established that it is the vagueness, inaccuracy of the signs of definition of psychological violence that is an obstacle in the formation of the subject of evidence in cases of issuing a restrictive order when psychological violence is committed. The actions that are psychological violence from the point of view of the legislative definition are analyzed. It is proposed to introduce mandatory training on psychological violence of a psychologist in cases of issuing a restrictive order to provide a mandatory opinion on the existence of psychological violence and the victim's fears for their own safety or the safety of third parties.

Recommendations are provided for the mandatory participation of a psychologist in the consideration of cases on the issuance of a restraining order on the basis of the use of psychological violence.

Key words: restrictive order, COVID-19, domestic violence, psychological violence, European Court of Human Rights. 